\title{
Can people with asymptomatic or pre-symptomatic COVID-19 infect others: a systematic review of primary data
}

Nelson Aguirre-Duarte M.D, PhD

Health Systems Department, School of Population Health

The University of Auckland, New Zealand.

n.aguirre@auckland.ac.nz

\begin{abstract}
Asymptomatic but infectious people have been reported in many infectious diseases. Asymptomatic and pre-symptomatic carriers would be a hidden reservoir of COVID-19.
\end{abstract}

\begin{abstract}
Aim
This review identifies primary empirical evidence about the ability of asymptomatic carriers to infect others with COVID-19 pandemic and reflects on the implications for control measures.
\end{abstract}

\section{Methods}

A systematic review is followed by a narrative report and commentary inclusion criteria were: studies reporting primary data on asymptomatic or presymptomatic patients, who were considered to have passed on COVID-19 infection; and published in indexed journals or in peer review between January 1 and March 31, 2020.

\section{Results}

Nine articles reported on 83 asymptomatic or pre-symptomatic persons.

\section{Conclusions}

The evidence confirms COVID-19 transmission from people who were asymptomatic at the time. A series of implications for health service response are laid out.

Keywords: Covid-19, Asymptomatic, Pre-symptomatic, Public Health 
medRxiv preprint doi: https://doi.org/10.1101/2020.04.08.20054023; this version posted April 16, 2020. The copyright holder for this preprint (which was not certified by peer review) is the author/funder, who has granted medRxiv a license to display the preprint in perpetuity.

All rights reserved. No reuse allowed without permission.

\section{Introduction:}

Asymptomatic but infectious people have been reported in many infectious diseases (Fraser, Riley, Anderson, \& Ferguson, 2004; Jartti, Jartti, Peltola, Waris, \& Ruuskanen, 2008). Examples include herpes, cytomegalovirus and respiratory diseases caused by viruses such as $\mathrm{H} 1 \mathrm{~N} 1$ or H5N1 influenza (Fielding, Kelly, \& Glass, 2015; Gu et al., 2011; Khanna, Kumar, Gupta, \& Kumar, 2012; Le et al., 2013; Powell et al., 2012). Asymptomatic and presymptomatic people are a reservoir hidden for detection systems.

Coronavirus disease 2019 (COVID-19), has infected more than 857 thousand people globally, resulting in more than 42 thousand deaths in a period of three months according to John Hopkins website (Dong, Du, \& Gardner, 2020).

The Chinese government first reported the infection as pneumonia of unknown origin in late December 2019; then in late January 2020, the WHO declared the outbreak a Public Emergency of International Concern, and on 11 March was elevated the alert level to pandemic (WHO, 2020a, 2020b). The epicentre of the disease was Wuhan City in Hubei Province in central China. Three characteristics were identified in the infection: an $83 \%$ attack rate declared as highly alarming, a wide spectrum of clinical manifestations in the patients (ranging from minor symptoms to pneumonia and death) along with evidence of the virus in a minority without any evidence of symptoms. The infection quickly spread in China and then cases began to be exported internationally (Mizumoto, Kagaya, \& Chowell, 2020; Wu et al., 2020).

There is increasing evidence supporting the contribution to the spread of infection by asymptomatic and pre-symptomatic patients with COVID-19. The speed with which the infection spreads suggests that transmission from unidentified (because asymptomatic) cases plays a substantial role in the exponential increase in the number of infected patients. This review seeks empirical evidence about the presence of asymptomatic and pre-symptomatic carriers in the current COVID-19 pandemic and offers reflections on the implications in the context of the current measures taken to control it.

\section{Method:}

This study reports a systematic literature review, a tabular summary of primary studies, and a narrative commentary on the implications. Databases searched were: MEDLINE, PubMed and Google academic (which includes pre- peer reviewed articles) using search terms "coronavirus", "COVID-19", "asymptomatic patients", and "pre-symptomatic patients". Inclusion criteria were reports of primary data pointing to infection from contact with asymptomatic or pre-symptomatic persons; publication in indexed journals or in the process of peer review between January 1 and March 31, 2020. The references of included articles were scanned for further relevant sources (snowball process). Publications in English, Spanish, Mandarin and Korean were accepted. 
medRxiv preprint doi: https://doi.org/10.1101/2020.04.08.20054023; this version posted April 16, 2020. The copyright holder for this preprint (which was not certified by peer review) is the author/funder, who has granted medRxiv a license to display the preprint in perpetuity.

All rights reserved. No reuse allowed without permission.

References were managed using EndNote v8 and MAXQDA v11(Oliveira, Bitencourt, Teixeira, \& Santos, 2013).

\section{Results:}

Two hundred eight abstracts were identified as potentially relevant, reduced to nine finally included, as detailed in Figure 1. reviewed, and the selection criteria applied. Twenty-five scientific articles were selected for content analysis. Through a review of bibliographic references, seven new articles were included (Fig 1). A total of nine articles were identified as empirical evidence of the presence of asymptomatic or pre-symptomatic patients with COVID-19 infection. Table 1 presents the current evidence.

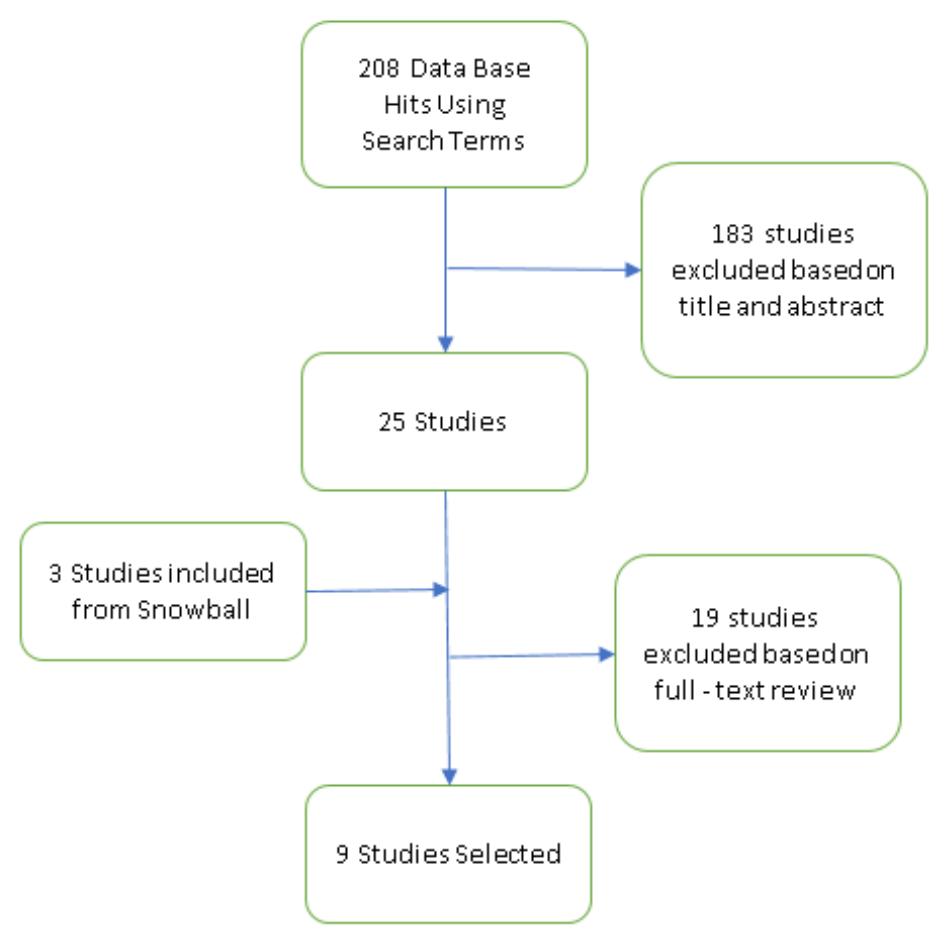

Fig.1 Description of the study selection process 


\begin{tabular}{|c|c|c|c|c|c|c|c|c|}
\hline $\begin{array}{l}\text { Date / period } \\
\text { of the } \\
\text { presentation } \\
\text { / exposure }\end{array}$ & $\begin{array}{c}\mathrm{N} \\
\text { asymptomatic } \\
\text { or pre- } \\
\text { symptomatic }\end{array}$ & Age (years) & Gender & $\begin{array}{c}\text { Residence } \\
\text { country/city of } \\
\text { asymptomatic } \\
\text { patient }\end{array}$ & $\begin{array}{c}\text { Place of } \\
\text { diagnostic }\end{array}$ & Context & Type of patient & Reference \\
\hline $\begin{array}{l}\text { Dec } 8,2019- \\
\text { February } 6 \\
2020\end{array}$ & 1 & 0.7 & Female & Wuhan/China & Wuhan/China & $\begin{array}{l}\text { Retrospective study on } \\
\text { all hospitalised infants } \\
\text { diagnosed with COVID- } \\
19.1 \text { patient was } \\
\text { asymptomatic over } 9 \\
\text { patients. This patient is } \\
\text { related to } 5 \text { infected } \\
\text { family members. }\end{array}$ & Asymptomatic & (Wei et al., 2020) \\
\hline Jan 10, 2020 & 1 & 20 & Female & Wuhan/China & Anyang/China & $\begin{array}{l}\text { This woman from } \\
\text { Wuhan visited her } \\
\text { family in Anyang. Then } \\
\text { her family presented } \\
\text { symptoms and } x \text { were } \\
\text { confirmed infected. The } \\
\text { woman was positive for } \\
\text { COVID-19 PCR, but } \\
\text { she never presented } \\
\text { symptoms despite } \\
\text { having had multifocal } \\
\text { ground-glass opacities } \\
\text { on chest CT, with } \\
\text { subsegmental areas of } \\
\text { consolidation and } \\
\text { fibrosis. }\end{array}$ & Asymptomatic & (Bai et al., 2020) \\
\hline Jan 10, 2020 & 1 & 10 & Male & Shenzhen/China & Wuhan/China & $\begin{array}{l}\text { This study reports } \\
\text { clinical results of a } \\
\text { family cluster of } 5 \\
\text { people infected with } \\
\text { COVID-19. The patient } \\
\text { referred as } 5 \text {, was } \\
\text { asymptomatic despite } \\
\text { ground glass opacities } \\
\text { identified by CT scan. }\end{array}$ & Asymptomatic & (Chan et al., 2020) \\
\hline
\end{tabular}




\begin{tabular}{|c|c|c|c|c|c|c|c|c|}
\hline $\begin{array}{l}\text { Jan } 11 \text { to Feb } \\
29,2020\end{array}$ & 55 & $\begin{array}{c}\text { Ages } 2 \text { to } 69 \\
\text { years, median } \\
49 \text { years. The } \\
\text { proportion of } \\
\text { asymptomatic } \\
\text { cases aged } \\
\text { from } 30 \text { to } 49 \\
\text { years old was } \\
30.9 \%\end{array}$ & $\begin{array}{l}22 \text { Male } \\
33 \mathrm{~F}\end{array}$ & Shenzhen/China & Shenzhen/China & $\begin{array}{l}\text { This a retrospective } \\
\text { analysis on } \\
\text { asymptomatic patients } \\
\text { admitted to a hospital } \\
\text { after their family } \\
\text { member's diagnoses of } \\
\text { COVID-19. All patients } \\
\text { were asymptomatic at } \\
\text { the time of the test. } 14 \\
\text { mild, } 39 \text { moderate and } 2 \\
\text { severe during } \\
\text { hospitalization }\end{array}$ & Pre-symptomatic & (Y. Wang et al., 2020) \\
\hline Jan 19, 2020 & 1 & $\mathrm{NI}$ & Female & Shanghai & Germany & $\begin{array}{l}\text { This asymptomatic } \\
\text { woman attended } \\
\text { business meetings in } \\
\text { Germany. Then } 4 \\
\text { people were COVID-19 } \\
\text { PCR positive. }\end{array}$ & Pre-symptomatic & (Rothe et al., 2020) \\
\hline $\begin{array}{l}\text { Jan } 28 \text { to Feb } \\
9,2020\end{array}$ & 24 & $\begin{array}{l}\text { Ages } 5 \text { to } 95 \\
\text { years old. } \\
\text { (median 32.5) }\end{array}$ & $\begin{array}{l}8 \text { Males } \\
16 \mathrm{~F}\end{array}$ & Nanjing/China & $\begin{array}{l}33.3 \% \text { had history } \\
\text { of recent travel to } \\
\text { Hubei }\end{array}$ & $\begin{array}{l}\text { Investigation of all close } \\
\text { contacts of COVID-19 } \\
\text { patients, both in clinic } \\
\text { and community in one } \\
\text { city. All } 24 \text { cases were } \\
\text { identified as } \\
\text { asymptomatic carriers. }\end{array}$ & Asymptomatic & (Hu et al., 2020) \\
\hline
\end{tabular}




\begin{tabular}{|c|c|c|c|c|c|c|c|c|}
\hline Jan 29, 2020 & 5 & $\mathrm{NI}$ & $\mathrm{NI}$ & Japan & Wuhan/China & $\begin{array}{l}565 \text { Japanese citizens } \\
\text { were evacuated from } \\
\text { Wuhan. Healthy } \\
\text { individuals were in } \\
\text { quarantine. All people } \\
\text { were screened for } \\
\text { symptoms prior to } \\
\text { disembarkation. All } \\
\text { tested for COVID-19 } \\
\text { PCR. } 5 \text { of them were } \\
\text { positive and } \\
\text { asymptomatic at the } \\
\text { time of the test. }\end{array}$ & Asymptomatic & (Nishiura et al., 2020) \\
\hline Feb 5, 2020 & 255 & $\begin{array}{l}(0-9) 1,(10-) 1, \\
(20-) 2,(30-) 5, \\
(40-) 7,(50-) 22, \\
(60-) 56,(70- \\
136,(80-) 25, \\
(90-) 0\end{array}$ & $\mathrm{NI}$ & $\begin{array}{l}\text { Multiple } \\
\text { precedence - } \\
\text { diamond } \\
\text { Princess Cruise } \\
\text { Ship }\end{array}$ & Yokohama/Japan & $\begin{array}{l}521 \text { people tested } \\
\text { positive for COVID-19 } \\
\text { over } 3711 \text { passengers } \\
\text { and crew members. " } \\
\text { the crude asymptomatic } \\
\text { ratio, a simple } \\
\text { proportion of } \\
\text { asymptomatic infections } \\
\text { among all the infections } \\
\text { was estimated as } \\
\text { follows: } 66.7 \% \text { ( } 95 \% \\
\text { Confidence Interval } \\
\text { (95\%Cl): } 9.4 \%, 99.1 \%) \\
\text { for aged } 0-19 \text { years, } \\
30.8 \%(95 \% \mathrm{Cl}: 22.6 \% \text {, } \\
40.0 \%) \text { for aged } 20-58 \\
\text { years and } 52.8 \% \\
(95 \% \mathrm{Cl}: 47.9 \%, 57.5 \%) \\
\text { for aged } 60 \text { years and } \\
\text { older (95\%Cl is based } \\
\text { on binomial } \\
\text { distribution)." }\end{array}$ & Asymptomatic & (Mizumoto \& Chowell, 2020) \\
\hline
\end{tabular}




\begin{tabular}{|c|c|c|c|c|c|c|c|c|}
\hline Feb 6, 2020 & 1 & 50 & Female & Anqing/China & Anqing/China & $\begin{array}{l}\text { This woman had a test } \\
\text { for COVID-19 as her } \\
\text { husband's close contact } \\
\text { with positive patients. } \\
\text { She had a confirmed } \\
\text { positive result. She also } \\
\text { received treatment with } \\
\text { antivirals and five days } \\
\text { after treatment both } \\
\text { throat and anal swaps } \\
\text { were still positive. This } \\
\text { patient was an } \\
\text { asymptomatic positive } \\
\text { carrier. }\end{array}$ & Asymptomatic & $(\text { Luo et al. })^{*}$ \\
\hline
\end{tabular}

$\mathrm{NI}=$ No Informed

${ }^{*}$ Study publish in ChinaXiv.org

Table 1. Current evidence of asymptomatic and pre-symptomatic COVID-19 patients 
medRxiv preprint doi: https://doi.org/10.1101/2020.04.08.20054023; this version posted April 16, 2020. The copyright holder for this preprint (which was not certified by peer review) is the author/funder, who has granted medRxiv a license to display the preprint in perpetuity.

All rights reserved. No reuse allowed without permission.

\section{Discussion}

This review presents the available evidence that asymptomatic and presymptomatic people can infect others with COVID-19. As for other viral infections, this may play an essential role in community transmission. The specific of proactive interventions should be considered during a pandemic that includes asymptomatic transmission.

\section{Implications for risk management and preparedness}

it seems that the lessons learnt from previous pandemics have not been applied, and countries did not adequately assess the risks, and as a result, there has been a lack of resources and response plans adequate to save lives (Anderson, Heesterbeek, Klinkenberg, \& Hollingsworth, 2020). The presence of asymptomatic and pre-symptomatic carriers imposed an extra challenge on how to protect the public in general and front-line workers from the infection when an undetected infective person is present. A shortage of medical supplies is not uncommon in public health emergencies. Therefore, national and international medical supplies programmes before emergencies arise need to be strengthened (Wong, Leo, \& Tan, 2020).

\section{Implications for healthcare workers protection and health systems response}

Asymptomatic and pre-symptomatic patients are a source of active risk for front line workers. It imposes an additional challenge to the health system as undetected patients can spread the infection and affect the level of response ( $\mathrm{J}$. Wang, Zhou, \& Liu, 2020). The use of personal protective equipment by all front-line workers should be mandatory. Shortages of masks, goggles are unacceptable because the risk of infection and death of these workers may affect the whole health system response to the community (Schwartz, King, \& Yen, 2020).

\section{Implication for infection modelling and planning.}

Mathematical models in the context of COVID-19 have demonstrated their usefulness in simulating transmission trends, risk assessment, epidemic development, and the effects of isolation and quarantine (Tang, Xiao, Peng, \& Shen, 2020). However, missing the effect of asymptomatic or pre-symptomatic stages of the disease, introduces errors into prediction models (Gaeta, 2020; Tian et al., 2020).

\section{Implications for testing approaches}

A rapid, systematic and widespread approach to testing is needed to detect new cases in the community and in front-line workers. Maintaining restrictions in testing is not the best way to identify asymptomatic and pre-symptomatic patients (C. J. Wang, Ng, \& Brook, 2020). The worst-case scenario is to have asymptomatic or pre-symptomatic COVID-19 front-line workers because they can potentially infect vulnerable patients and their families. The testing approaches must be easily adaptable for the needs of the community and 
medRxiv preprint doi: https://doi.org/10.1101/2020.04.08.20054023; this version posted April 16, 2020. The copyright holder for this preprint (which was not certified by peer review) is the author/funder, who has granted medRxiv a license to display the preprint in perpetuity.

All rights reserved. No reuse allowed without permission.

clusters of interest. The speed of the detection and fast response could be a critical success factor (Maclntyre \& Heslop, 2020) (Ferretti et al., 2020)

\section{Implications for immigration restrictions}

Temperature scanners and self-report of symptoms at international airports must necessarily fail to detect asymptomatic and pre-symptomatic patients. Self-isolation plus more systematic testing could prevent undetected dissemination. A more robust public health response must be developed in the border.

Special attention needs to be paid to front-line workers in airlines and other crew members. Asymptomatic patients could be a source of infection to these people and airline crew who themselves asymptomatic carriers are a risk to passengers. Airline companies should reflect on how to protect the crew and minimise the risk of dissemination (Mouchtouri, Dirksen-Fischer, \& Hadjichristodoulou, 2020), probably by routine testing and use of personal protective equipment.

\section{Implications in social connectedness (physical distance and clusters)}

Physical distance is a paramount approach to avoid COVID-19 infection, but the presence of asymptomatic patients in the community and front-line workers should be enough reason to wear face mask and goggles in public and healthcare places. The virus is present in saliva, which could be spread in the form of exhaled air (over a short distance) or droplets (over a longer distance (Bourouiba, 2020). At a community level, transmission undetected infective persons are highly likely.

These strategies should apply until a specific vaccine is available, even if effective treatments become available first. This pandemic has changed the way we interact as individuals and how to respond as communities to a severe challenge to public health. The number of deaths indicates there is substantial room for improvement is significant in the way governments and global health organisations need to operate. Next time, we would aim to more rapidly identify and disseminate information about a cluster of new disease, and a more coordinated and faster global response could isolate such a cluster and prevent rapid dissemination to the entire world.

\section{Limitations}

Those studies selected in this review had several limitations. Many have a small sample size. Several studies note the low sensitivity or specificity of available diagnostic tools; relevant symptoms were difficult to identify in some patients (for the infant study case in particular); and in some cases, relevant dates were while there were reporting delays with others. However, given the recent presentation of this disease and the lack of formal studies in this short period, this information is relevant to public health policy and protection for populations and healthcare and other front-line workers. 


\section{Conflict of Interest:}

Selection of "no competing interests" reflects that the author have completed the ICMJE uniform disclosure form at www.icmje.org/coi_disclosure.pdf and declare: no support from any organization for the submitted work; no financial relationships with any organizations that might have an interest in the submitted work in the previous three years; no other relationships or activities that could appear to have influenced the submitted work.

\section{Acknowledgement:}

I wish to thank Dr T Kenealy for a helpful review of this manuscript. 


\section{Reference List}

Anderson, R. M., Heesterbeek, H., Klinkenberg, D., \& Hollingsworth, T. D. (2020). How will country-based mitigation measures influence the course of the COVID-19 epidemic? The Lancet, 395(10228), 931-934. doi:10.1016/s0140-6736(20)30567-5

Bai, Y., Yao, L., Wei, T., Tian, F., Jin, D.-Y., Chen, L., \& Wang, M. (2020). Presumed asymptomatic carrier transmission of COVID-19. JAMA.

Bourouiba, L. (2020). Turbulent Gas Clouds and Respiratory Pathogen Emissions: Potential Implications for Reducing Transmission of COVID-19. JAMA. doi:10.1001/jama.2020.4756

Chan, J. F.-W., Yuan, S., Kok, K.-H., To, K. K.-W., Chu, H., Yang, J., . . Poon, R. W.-S. (2020). A familial cluster of pneumonia associated with the 2019 novel coronavirus indicating person-to-person transmission: a study of a family cluster. The Lancet, 395(10223), 514-523.

Dong, E., Du, H., \& Gardner, L. (2020). An interactive web-based dashboard to track COVID-19 in real time. The Lancet infectious diseases.

Ferretti, L., Wymant, C., Kendall, M., Zhao, L., Nurtay, A., Abeler-Dörner, L., . . Fraser, C. (2020). Quantifying SARS-CoV-2 transmission suggests epidemic control with digital contact tracing. Science.

Fielding, J. E., Kelly, H. A., \& Glass, K. (2015). Transmission of the First Influenza A(H1N1)pdm09 Pandemic Wave in Australia Was Driven by Undetected Infections: Pandemic Response Implications. PloS one, 10(12), e0144331-e0144331. doi:10.1371/journal.pone.0144331

Fraser, C., Riley, S., Anderson, R. M., \& Ferguson, N. M. (2004). Factors that make an infectious disease outbreak controllable. Proceedings of the National Academy of Sciences of the United States of America, 101(16), 6146-6151. doi:10.1073/pnas.0307506101

Gaeta, G. (2020). A simple SIR model with a large set of asymptomatic infectives. arXiv preprint arXiv:2003.08720.

Gu, Y., Komiya, N., Kamiya, H., Yasui, Y., Taniguchi, K., \& Okabe, N. (2011). Pandemic (H1N1) 2009 transmission during presymptomatic phase, Japan. Emerging infectious diseases, 17(9), 1737-1739. doi:10.3201/eid1709.101411

Hu, Z., Song, C., Xu, C., Jin, G., Chen, Y., Xu, X., . . Zheng, Y. (2020). Clinical characteristics of 24 asymptomatic infections with COVID-19 screened among close contacts in Nanjing, China. Science China Life Sciences, 1-6.

Jartti, T., Jartti, L., Peltola, V., Waris, M., \& Ruuskanen, O. (2008). Identification of respiratory viruses in asymptomatic subjects: asymptomatic respiratory viral infections. The Pediatric infectious disease journal, 27(12), 1103-1107.

Khanna, M., Kumar, B., Gupta, A., \& Kumar, P. (2012). Pandemic Influenza A H1N1 (2009) Virus: Lessons from the Past and Implications for the Future. Indian journal of virology : an official organ of Indian Virological Society, 23(1), 12-17. doi:10.1007/s13337-0120066-3

Le, M. Q., Horby, P., Fox, A., Nguyen, H. T., Le Nguyen, H. K., Hoang, P. M. V., . . van Doorn, H. R. (2013). Subclinical avian influenza A (H5N1) virus infection in human, Vietnam. Emerging infectious diseases, 19(10), 1674.

Luo, S., Liu, W., Liu, Z., Zheng, X., Ling, P., Ding, Y., ... Weng, J. Confirmed asymptomatic carrier of SARS-CoV-2.

Maclntyre, C. R., \& Heslop, D. J. (2020). Public health, health systems and palliation planning for COVID-19 on an exponential timeline. The Medical Journal of Australia, 1.

Mizumoto, K., \& Chowell, G. (2020). Transmission potential of the novel coronavirus (COVID19) onboard the Diamond Princess Cruises Ship, 2020. Infectious Disease Modelling. 
medRxiv preprint doi: https://doi.org/10.1101/2020.04.08.20054023; this version posted April 16, 2020. The copyright holder for this preprint (which was not certified by peer review) is the author/funder, who has granted medRxiv a license to display the preprint in perpetuity.

All rights reserved. No reuse allowed without permission.

Mizumoto, K., Kagaya, K., \& Chowell, G. (2020). Transmissibility of 2019 Novel Coronavirus: zoonotic vs. human to human transmission, China, 2019-2020. medRxiv.

Mouchtouri, V. A., Dirksen-Fischer, M., \& Hadjichristodoulou, C. (2020). Health measures to travelers and cruise ships in response to COVID-19. Journal of Travel Medicine. doi:10.1093/jtm/taaa043

Nishiura, H., Kobayashi, T., Yang, Y., Hayashi, K., Miyama, T., Kinoshita, R., . . Suzuki, A. (2020). The rate of underascertainment of novel coronavirus (2019-nCoV) infection: Estimation using Japanese passengers data on evacuation flights: Multidisciplinary Digital Publishing Institute.

Oliveira, M., Bitencourt, C., Teixeira, E., \& Santos, A. C. (2013). Thematic content analysis: Is there a difference between the support provided by the MAXQDA ${ }^{\circledR}$ and NVivo ${ }^{\circledR}$ software packages. Paper presented at the Proceedings of the 12th European Conference on Research Methods for Business and Management Studies.

Powell, T. J., Fox, A., Peng, Y., Quynh Mai, L. T., Lien, V. T., Hang, N. L., . . McMichael, A. J. (2012). Identification of H5N1-specific T-cell responses in a high-risk cohort in vietnam indicates the existence of potential asymptomatic infections. Journal of Infectious Diseases, 205(1), 20-27.

Rothe, C., Schunk, M., Sothmann, P., Bretzel, G., Froeschl, G., Wallrauch, C., .. Guggemos, W. (2020). Transmission of 2019-nCoV infection from an asymptomatic contact in Germany. New England Journal of Medicine.

Schwartz, J., King, C.-C., \& Yen, M.-Y. (2020). Protecting Healthcare Workers During the Coronavirus Disease 2019 (COVID-19) Outbreak: Lessons From Taiwan's Severe Acute Respiratory Syndrome Response. Clinical Infectious Diseases. doi:10.1093/cid/ciaa255

Tang, S., Xiao, Y., Peng, Z., \& Shen, H. (2020). Prediction modeling with data fusion and prevention strategy analysis for the COVID-19 outbreak. Zhonghua liu xing bing xue za zhi= Zhonghua liuxingbingxue zazhi, 41(4), 480.

Tian, L., Li, X., Qi, F., Tang, Q.-Y., Tang, V., Liu, J., . . Liu, H. (2020). Pre-symptomatic Transmission in the Evolution of the COVID-19 Pandemic. arXiv preprint arXiv:2003.07353.

Wang, C. J., Ng, C. Y., \& Brook, R. H. (2020). Response to COVID-19 in Taiwan: Big Data Analytics, New Technology, and Proactive Testing. JAMA. doi:10.1001/jama.2020.3151

Wang, J., Zhou, M., \& Liu, F. (2020). Reasons for healthcare workers becoming infected with novel coronavirus disease 2019 (COVID-19) in China. J Hosp Infect. doi:10.1016/j.jhin.2020.03.002

Wang, Y., Liu, Y., Liu, L., Wang, X., Luo, N., \& Ling, L. (2020). Clinical outcome of 55 asymptomatic cases at the time of hospital admission infected with SARS-Coronavirus2 in Shenzhen, China. The Journal of Infectious Diseases.

Wei, M., Yuan, J., Liu, Y., Fu, T., Yu, X., \& Zhang, Z.-J. (2020). Novel coronavirus infection in hospitalized infants under 1 year of age in China. JAMA.

WHO. (2020a). Novel coronavirus press conference at United Nations of Geneva 29 January 2020 [Press release]

WHO. (2020b). WHO Director-General's opening remarks at the media briefing on COVID-19 11 March 2020. Retrieved from https://www.who.int/dg/speeches/detail/whodirector-general-s-opening-remarks-at-the-media-briefing-on-covid-19---11-march$\underline{2020}$

Wong, J. E. L., Leo, Y. S., \& Tan, C. C. (2020). COVID-19 in Singapore-Current Experience: Critical Global Issues That Require Attention and Action. JAMA. doi:10.1001/jama.2020.2467

Wu, J. T., Leung, K., Bushman, M., Kishore, N., Niehus, R., de Salazar, P. M., . . L Leung, G. M. (2020). Estimating clinical severity of COVID-19 from the transmission dynamics in Wuhan, China. Nature Medicine, 1-5. 